\title{
Tirta Amerta Sari: Syukuran and Slametan for Holy Water
}

\author{
Nanang Bustanul Fauzi ${ }^{1}$, Jamila Wijayanti ${ }^{2}$, Machrus Abadi ${ }^{3}$ \\ \{banyubening@ub.ac.id ${ }^{1}$ \} \\ Universitas Brawijaya, Indonesia ${ }^{1,2,3}$
}

\begin{abstract}
The purpose of this study was to describe Tirta Amerta Sari ritual. Tirta Amerta Sari ritual is held by the Sumberawan community as a form of gratitude as well as praying together with the local community (slametan). This form of gratitude is carried out on the basis of the abundance of water from water sources by bringing the produce to the area (outside) of the temple which ends with a meal together. Meanwhile, the slametan is carried out with the mythological tracing ritual of Tirta Amerta Sari which was fought over by the gods and giants. The ritual is divided into three parts, namely community service, istighosah and sending prayers, and is closed with a procession of Tirta Amerta Sari. As the findings sum, it is interesting to research it in the spirit of multiculturalism while preserving the tradition.
\end{abstract}

Keywords: Ceremony, Ritual, Syukuran, Slametan, Tirta Amerta Sari

\section{Introduction}

Toyomarto Village is located in the Singosari District, Malang Regency, with an area of approximately 905 hectares. As one of villages in Singosari, Toyomarto has also a vision and mission. The vision of Toyomarto village is "the development of good and clean village governance in order to realize a just, prosperous, and prosperous village community life to create togetherness, harmony towards civil society" (Village Government Administration Report, 2018: 8). The mission of Toyomarto village, namely: (1) encouraging the community to complete the compulsory 9 years of basic education and also optimizing the role of Community Learning Activity Center or Pusat Kegiatan Belajar Masyarakat (PKBM) in the development of out-of-school education through pursuing degree without school enrolling (it is called kejar paket); (2) promoting environmental health and healthy lifestyles; (3) encouraging the strengthening and development of cooperative roles; (4) encouraging the strengthening of guidance in empowering the role of women and young people as well as the potential of other communities; (5) strengthening of the community's economy from village potential through Small and Medium Enterprises (SMEs), especially the development of tourism and home industry; and (6) strengthening of the improvement of the quality of a harmonious social life based on the spirit of mutual cooperation and the values of good virtues (akhlaqul karimah).

Toyomarto Village has various potential resources, namely: tourism potential, agricultural potential, livestock potential, and home industry potential. The tourism potential in Toyomarto village is Sumberawan Temple, Trisula Musik Kontemporer (Contemporary Music Trident), Tirta Amerta Sari Ceremony, sand mining object, plantation tourism, and livestock tourism. Wisata Candi Sumberawan (Sumberawan Temple Tour) is located in Sumberawan sub-village, 
Toyomarto village. Every Javanese New Year, Sumberawan Temple is used for ritual ceremonies called Tirta Amerta Ritual. The Toyomarto Village Government has routinely held the Tirta Amerta Sari ritual every suro month (suro is one of twelve months in Javanese calendar). The event was opened with a traditional dance, releasing fish, releasing birds and taking Tirta Amerta. The ritual is held as an expression of gratitude to God Almighty and blessings to the life given as the villagers' prosperity during a year of living.

The ceremony is one of folklores of the Sumberawan people. Folklore is a culture that is owned by a community group, is traditional in nature, and is carried out by the supporting communities from generation to generation. According to Endraswara [1], folklore is passed down from generation to generation in accordance with the traditions of the local community as a regional cultural heritage. Folklore is in the form of folk beliefs or superstitions, customs, performances, traditional dance, folk science, and folk poetry. Thus, folklore is not only a verbal form but also a cultural expression that is carried out because of the people's beliefs or superstitions [2]. As folklores are different in each area, research on local wisdom by observing traditions carried out by certain groups of people aims to determine the meaning and cultural values contained therein. These various modern values shift the value of local wisdom so that people experience an identity crisis in the youth generation of the village [3].

The idea of local wisdom preservation in the area as the basis for carrying out character education in each of its lines has long been echoed. This is supported by the fact that a particular society or community has a unique way of solving problems and at the same time instilling moral values. Through this traditional ceremony, people promote noble values in the form of life that must be in balance with nature as a provider. In the development of the village's vision and mission that prioritizes tourism potential, this ceremony is included in the projection of village development and cultural public agenda. However, the values, functions and roles are less echoed by traditional actors. The ceremony is only an annual practice without adequate concepts and structures so that it is able to carry out its vision, both as a sacred ritual and preservation of noble values as well as an object predicted to have the potential to attract tourists. Therefore, this research is here to answer the challenges ahead about how the structure of the Tirta Amerta Sari ceremony, both literally and inwardly in each process.

Based on the background discussed, the research question or problem formulation in this study was "How the meaning and values in the Tirta Amerta Sari ritual in Toyomarto Village, Singosari District, Malang Regency?". Therefore, this research aimed to describe the meaning and cultural values we found in Tirta Amerta Sari ceremony in Toyomarto village. This research is expected to be useful theoretically and practically. The theoretical benefit is that we can learn about the values and the meaning behind Tirta Amerta Sari ceremony as if we can add literatures through empirical study to educate people who are not knowing about Tirta Amerta Sari. Practically, the results of this study can be positioned as one of preserving cultural heritage attempts in Malang Regency.

\section{Research Method}

\subsection{Research Type and Approach}

This research used a qualitative approach. The data obtained were in the form of qualitative data from interviews with the caretaker of the Sumberawan Temple, village elders, and local village officials. The data analysis process used a qualitative approach, without statistical 
calculations [4]. The results of this analysis were interpreted, validated or checked by the data validity, and reported in descriptions forms. The design used in this study was a qualitative descriptive design.

\subsection{Field Observation}

In this study, the presence of researchers in qualitative research is absolutely necessary because the researcher acts and becomes an instrument for collecting data or observations. To collect and determine qualitative data, researchers use a set of instruments as a means of collecting data. The instruments used consist of the main and supporting instruments. The main instrument is the researcher himself [5]. The supporting instruments used were interview guides, documentation, and photos, literature study [6].

\subsection{Data Sources}

The data in this study were collected from interviews with people included in Tirta Amerta Sari ceremony and people surrounding the village who know deeply about Tirta Amerta Sari. As the data were obtained through verbal analysis, primary data and secondary data were needed to perform data triangulation. The method can help strengthening the data results before analysis. People who were included in this research had given their consent in taking into the interviews and observation.

\subsection{Data Collecting Procedure}

The data collection technique used in this study was the interview technique. This technique is described in various technical forms according to the various tools. Before conducting the interview, first virtual observations will be made. This is done considering that the holding of this ceremony does not coincide with the research being carried out. These observations were carried out with the help of village officials who already had video documentation. Through this video several reference sources will be determined as well as interview guidelines. After the virtual observations have been made, the next step is to interview the selected sources. Interviews were conducted by going to the field accompanied by local village officials. On one occasion, informal interviews will be conducted to obtain more complete and in-depth data to get the information about Tirta Amerta Sari in Toyomarto village.

\subsection{Data Analysis}

Data analysis was carried out in a descriptive interpretive manner. Interpretative descriptive method is conducted by several steps. The data obtained are interpreted in accordance with existing natural data by reducing data, selecting appropriate data, identifying, analyzing, and describing data. The parameters used in this study refer to the structure of the ceremony as part of the performing arts considering the projection of its function and role in the future as part of village tourism objects. 


\section{Result and Findings}

\subsection{Tirta Amerta Sari Ritual Overview}

In the beginning, this ritual was a ritual of thanksgiving for the Sumberawan sub-village community for the abundance of water in the area. During the $16^{\text {th }}$ century, local people looked for water sources around the temple. In groups where there are still blood relations between members, they distribute water to their respective homes. Increasingly, family members and neighbors also want water from that source. From these various groups, the rituals developed partially. This ritual has been running for decades in Sumberawan. The typical group ritual is only a simple ritual of gratitude by visiting a source that supports their household needs by bringing offerings (sesajen), praying, and eating together (bancakan). Gradually, this group grew further. Therefore, the association of drinking water users or Himpunan Pengguna Air Minum (HIPAM) was formed based on the discussion among villagers.

At the initiative of this research resource person, the routine rituals of these groups were put together in a big agenda for the celebration of the spring, namely Tirta Amerta Sari. This ritual agenda still maintains its original form, namely every suro month in Javanese calendar. Not only special rituals in the source area, Tirta Amerta Sari was expanded into several activity agendas. During Tirta Amerta Sari ritual, there are several activities and behaviors carried out, namely: community service, praying together, and Islamic carnival.

The first agenda is community service. It is represented by mutual cooperation is the opening act in the Tirta Amerta Sari ritual. It should be noted that the distribution of areas in Sumberawan is the development of HIPAM groups. On this basis, the community service groups were divided. The HIPAM groups will go down the river (towards the water source) and clean it. Apart from rivers, locations around springs will also be cleaned. The second agenda is praying together. This ritual is a special ritual of Islam held by the Muslim community in the area or Toyomerto village. There is no specific time in this event. In addition to spring salvation, this event is also devoted to sending prayers for village elders, namely the village head, village elders (kamituwo), and Sumberawan sub-village head. They also pray for the spirits who died from family members by performing the Islamic praying and Al-Qur'an reading called istighosah. The third agenda is Islamic Carnival. It is also called Kirab Selametan, a procession carried out by all residents from a location in the village to the water source. It is believed to be ready-to-eat food and local produce. The event agenda is held to act the gratitude of God's blessing for a-year-living in the village.

\subsection{The Meaning and Cultural Values of Tirta Amerta Sari Ritual}

Based on the interviews, observations, and field study we have conducted in Toyomerto village, we arranged the meaning and cultural values of Tirta Amerta Sari ritual. Basically, the rituals are performed annually to send gratitude to God's blessing in a year as if they can live in a year with prosperity, health, and kindness. They also expect and pray that the same condition can happen in their family once again through a year later. Therefore, there are deeper meaning and cultural values behind the rituals. We found three meanings and cultural values from Tirta Amerta Sari. 


\subsubsection{Community Service}

In the Tirta Amerta Sari ritual, community service is the opening event for this series of activities. Community service is seen as a form of love and loyalty from the local community to the continuity of nature that benefits them. This community service is carried out by cleaning the river flow along it. Starting from where they live (consisting of HIPAM and groups from sub-village per area or it is called Rukun Tetangga/RT) to the spring which is the source of their water needs. Cited from Unabridged Dictionary of the Indonesian Language or Kamus Besar Bahasa Indonesia (KBBI), community service is defined as mutual cooperation without wages, or in the context of a conversation, it is defined as work without compensation. This term can be harmonized with the term gotong-royong. Koentjaraningrat [7] defines gotong-royong as the mobilization of human labor without payment for a project or work that is beneficial to the public or that is useful for development. Mutual cooperation is often found in communities rooted in rural or agrarian farming traditions.

Tirta Amerta Sari ritual takes community service as the first activity in a series of thanksgiving activities. As explained in the first paragraph, this opening activity is carried out in order to preserve the environment. Awareness of protecting the environment in order to be sustainable is deeply embedded in the community. The flow of water is carried out along the river to the spring. In ecological awareness, this includes the fulfillment of the principle of being responsible for nature [8]. This is not only individual, but also collective. This principle requires humans to take real initiatives, efforts, policies and actions to protect nature and sustain the harmony between nature and human in the village area. This suggests that damage and preservation of nature is a shared responsibility.

\subsubsection{Praying Together}

The word "istighosah" is a masdar form or verbatim of "Fi'il Madli Istaghotsa" which means "asking for help". In terms of terminology, istighosah means certain praying in Arabic term to God's Almighty (wirid). It is done by reading Al-Qur'an to ask Allah SWT for help with some of the problems of life at hand. This wirid was compiled by K. H. Mohammad Romli Tamim in 1951 with evidence of his book, "Al-Istighatsah bi Hadrati Rabb al-Bariyyah" in the same year. In short, this istighosah is a collection of dhikr that is carried out with certain recitations and sequences. The purpose of this dhikr is to ask Allah for help so that it is kept away from all kinds of disasters and calamities to perform new season of planting.

In the context of Tirta Amerta Sari, this activity is also accompanied by sending prayers to the ancestors who are important figures in Sumberawan, especially the ancestors who cleared the first land (babat alas). In this istighosah, water taken from the source will be placed in containers for prayer. After the event, this water will be distributed to the congregation in attendance. This prayer water is believed to be a source of positive energy for the drinker (kept away from calamities in the area of village). Respect for ancestors is a practice of Javanese society in general. In various places, this is not uncommon, especially when there are events in the villages during the month of suro. In addition to getting closer to God, sending prayers accompanied by praying for water is categorized as respect for nature as the harmonious environment is achieved between them. Respect for nature is a basic principle for humans as part of the universe. Every member of the social community has an obligation to respect life with others (social cohesiveness). In short, nature has the right to be respected, not only because human life depends on nature, but also because of the ontological fact that humans are an 
integral part of nature, humans are members of the ecological community. Even the water they drink after doing istighosah can become an inseparable part of their life.

\subsubsection{Islamic Carnival}

This agenda begins with community leaders to go to the source area in the Sumberawan temple complex. the figures consisting of the head of the village and their entire apparatus, the head of the HIPAM group, will be accompanied by the customary leader and women carrying jugs (likened to an angel). The customary leader will accompany the head of the village and the women carrying the jugs to fetch water from the source. Meanwhile, the community people from the HIPAM group will bring their respective crops as a form of gratitude around the temple (outside the area). The water that has been contained in the seven jugs carried by the "seven angels" will be brought to the stage outside the temple area with walking.

On the stage, apart from the seven jugs of water, all kinds of crops were gathered as present. The speech is delivered by the head of the village followed by praying together and closed with a meal together. All those present will eat the produce and food that had been brought. Between residents will exchange food that is brought to eat together in the certain spot of area. The sharing food and crop is believed that it can bring peace and more prosperity to the community people because generosity is one of moral values achieved by the carnival as one of Tirta Amerta Sari. At the end, Islamic carnival usually closes the ritual.

\subsection{The Cultural Value of Tirta Amerta Sari Ritual}

The procession took the story of Tirta Amerta who was fought over by gods and giants. The story begins with the news that the amerta the gods and giants had been looking for was at the bottom of the vast and deep sea of milk (Ksirarnava) [9]. In an agreement made jointly by the gods and giants, Ksirarnava is planned to be continuously stirred by the two parties together. Mount Mandara was chosen as the "stick" for mixing it. Two cosmic dragon brothers, Anantabhoga and Basuki were also involved in this plan of taking water from the Tirta. The process begins with the breaking of Mount Mandara from its base by Naga Anantabhoga. Furthermore, Naga Basuki took the role of a piece of "rope" that wrapped around the fault of Mount Mandara which would be used as a "giant stick" stirring Ksirarnava. The neck of Basuki was held tightly by the giants, while his tail was in the tight grasp of the gods on the opposite side whatsoever. Then, the Ksirarnava stirring process began. When the giants grabbed the neck of Basuki, the gods extended their grip, and vice versa. The tug of war of the body of Naga Basuki took place alternately and continuously, until at least the huge Mount Mandara turned on its axis and stirred the Ksirarnava sea.

In order to prevent Mount Mandara from sinking to the bottom of Ksirarnava when rotated, Vishnu transformed into a cosmic tortoise named Kurma as a support for Mount Mandara on his back shield. At the same time, Vishnu, who was multiplying himself, also sat on the top of the Mandara Giri. In the middle of the Ksirarnava stirring process, various sacred objects and figures appeared which then played important roles in other Hindu mythologies. The most valuable thing is Tirta Amerta. Unfortunately, this eternal water fell into the hands of the giants. Lord Vishnu thought of a ploy to reclaim it. Finally, Lord Vishnu changed his form to become a very beautiful woman, named Mohini. The beautiful woman approached the asuras and rakshasas. They are very happy and captivated by the beauty of the incarnation woman Vishnu. After Lord Vishnu changed her form back, the giants became enraged and the war begun. Lord Vishnu produced a chakra weapon and Tirta Amerta is won back. 
Based on the historical value, Tirta Amerta Sari is seen as a form of thanksgiving as well as a blessing. The procession of crops that ends with a meal together (bancakan) is a manifestation of the Sumberawan community's gratitude for the gift of abundant springs. Meanwhile, the praying in the form of slametan is seen as a trace of the origin of water so that it is so valuable and profitable. In addition, submission is a prayer offered to God so that life will always be safe and be kept away from harm during a year after. Whereas from the ecological value perspective the ritual is explained as a cosmic consciousness built by cosmic solidarity (karma). Karma encourages humans to save the environment because nature and other life have the same value as human life. Karma functions as a moral controller, a kind of taboo in traditional society, to harmonize human behavior with the whole ecosystem. Cosmic solidarity serves to control human behavior within the limits of cosmic equilibrium. In Javanese belief, there are two cosmic concepts, namely macro and micro universe. The mind and the feeling belong to a world of their own which is God-centered. The act of slametan and bancakan in Tirta Amerta Sari ritual means carrying out their ancestral messages and maintaining good relations with them. The Javanese believe that ancestors have a significant role in protecting the village. Tirta Amerta Sari can be seen as preservation of water sources (nature) as verticaltranscendental relationships (with God and ancestors) and horizontal-social relationships with the community people.

In addition, the tension between followers of Islam and the Abangan community still occurs. Local community leaders rejected it because they thought the prayer in that place can endanger the faith because it was considered to be worshiping the temple. While the backstory of Tirta Amerta Sari is very Hindu, the local community, which are now majored by Moslem people, accepts the ritual as one of tolerance forms between Abangan and santri even though not all of Moslem people join the ritual. The distinction of Abangan and Moslem people still exists but there is no huge clash. The Moslem people, who rejects the ritual, tend to tolerate but they do not join the ritual process. Whereas the Moslem people who join the ritual are the ones with cultural heritage from their ancestors.

\section{Conclusion}

Tirta Amerta Sari ritual is a ritual held by the Sumberawan community as a form of gratitude as well as praying together (slametan). This form of gratitude is carried out on the basis of the abundance of water from water sources by bringing the produce to the area (outside) of the temple which ends with a meal together due to cosmic solidarity (karma), building harmony between humans and nature. Tirta Amerta Sari is divided into three parts, namely community service, istighosah and sending prayers, and is closed with a procession of Tirta Amerta Sari. In the past, this ritual was held in small groups in an event known as the slametan banyu.

\section{References}

[1] S. Endraswara, Antropologi sastra Jawa: konsep, kajian, dan aplikasi. Morfalingua, 2015.

[2] J. Danandjaja, Folklor Indonesia: ilmu gosip, dongeng, dan lain lain. Grafiti Pers, 1984.

[3] E. M. Setiadi, "Ilmu sosial dan budaya dasar," 2019.

[4] D. Iskandar and M. Pd, "Metodologi penelitian pendidikan dan sosial (kuantitatif dan kualitatif)." Jakarta: Gaung Persada Press, 2009.

[5] R. Bogdan and S. K. Biklen, Qualitative research for education. Allyn \& Bacon Boston, MA, 
1997.

[6] L. Moleong, Metodologi Penelitian Kualitatif. Bandung: PT. Remaja Rosdakarya, 2010.

[7] Koentjaraningrat, Kebudayaan, Mentalitas, dan Pembangunan. Jakarta: Gramedia Pustaka Utama, 1984.

[8] S. Keraf, Environmental Ethics. Jakarta: Kompas, 2006.

[9] S. Kramrisch, The Hindu Temple, vol. 1. Motilal Banarsidass Publ., 1976. 